\title{
Comparative morphological screening of some species of Cenchrus L. (Poaceae) from Thar Desert of Rajasthan, India.
}

Ganesh Kumar and Sunita Arora*

Department of Botany, JNVU, Jodhpur, Rajashtan, India.

Received: 2018-02-22; Accepted: 2018-03-01

\begin{abstract}
In present study an attempt has been made to describe widely confused species of Cencbrus (Poaceae). The exact identification has been critically assessed. The name Cenchrus comes from the Greek word "Kenchrous" meaning millet. Cenchrus is an extremely variable genus having both annual and perennial species. Morphologically Cenchrus is very similar to Pennisetum. All species of Cenchrus are very much similar in their morphology except few micromorphological distinctions. It is a xerophytic $\mathrm{C}_{4}$ grass, which grows in bunches and more often with creeping rhizomes. These grasses can exist under minimal level of precipitation ranging from as low as $95 \mathrm{~mm}$ to $1000 \mathrm{~mm}$. Cenchrus is very efficient in water usages as its root draws soil moisture rapidly as compared to other plants. Various traits are known to wild species of genus Cenchrus but due to lack of enough studies their full potential has not been exercised. An attempt has been need to study morphology of three species common in our region so that these details can further be utilized to exploit these species for their full potential.
\end{abstract}

Keywords: Bur, Cenchrus, Forage, Glume, Medicinal, Morphology, Plumose.

\section{Introduction}

Grasses feed the world either directly as food crops, such as wheat, rice, millets and other grains or indirectly as primary fodder for the livestock. It is estimated that grasslands cover around $20 \%$ of the earth's total area. Cenchrus a member of the tribe Paniceae of the Poaceae family is also one of the important components of major grass cover of the world. Cenchrus probably originated in the eastern tropical Africa and tropical Asia and widely naturalized in new world countries. Cenchrus is a species-rich grass genus of the arid and semi-arid tropical world. The Royal Botanic Garden; Kew has recorded 25 species while Germplasm Resource Information Network (GRIN) of USDA reported 35 different species of Cenchrus (Goel et al., 2011). Out of the 25 -species recorded, three are planted for forage across the world, with Cenchrus ciliaris being the most valued. $C$. ciliaris is new to cultivation and has not gone through bottleneck of domestication, due to which extreme variability exists in the wild at interspecific level. Apart from this species, other species also have been shown to have the potential for forage production and more tolerance toward harsh conditions. $C$. biflorus and $C$. setigerus have the capability to withstand heat and frost and can grow on wide range of soil types. Morphologically Cenchrus is more similar to Pennisetum which leads to confusion for identification but can be differentiated from each other by the morphology of the inner involucral bristles. In Cenchrus, bristles are fused with each other at the base forming a spiny cup while free in Pennisetum (Stieber and Wipff, 2000; Tu et al., 2002). That is the reason to

\footnotetext{
*Corresponding Author:

Dr. Sunita Arora,

Professor, Department of Botany,

JNVU, Jodhpur (Raj.), India.

E-mail: jnvusunitarora@gmail.com
}

treat C. ciliaris as Pennisetum ciliare (L.) Link (Chen and Kuoh, 2004). Cenchrus ciliaris grows mainly on sandy soil and alluvial plains, along roadside, rockyhillsides, hot and dry areas and denuded arid lands (Quattrocchi, 2008). C. ciliaris best suits for the restoration of degraded arid ecosystems (Visser et al., 2008; M'Seddi et al., 2002).

\section{Materials and Methods}

Fresh, disease free plant samples were collected from different places of arid region of Rajasthan (Barmer and Jodhpur), India during rainy season (July to September). Plant samples used for this study were collected directly from wild population. Plant parts were measured using hard ruler and were observed under dissecting and compound microscopes. For morphological studies 10 specimens per species used for assessment of morphological traits.

\section{Result and Discussion}

\section{Cenchrus ciliaris L.}

Common name - Buffel Grass

Herbaceous, Perennial with rhizomatous roots. Culm erect, divided into nodes and internodes possess 1-2 grooves. Internodes are $3-13 \mathrm{~cm}$ in length and $1-1.5 \mathrm{~cm}$ wide. Leaf simple, sessile, alternate, blades flat, linear, 21-52 cm long, 3-10 $\mathrm{mm}$ wide, acuminate at apex, both surface possess hair, that are more prickly and prominent on adaxial surface with long sheathing leaf base and hairy margine. Ligule membranous and ciliate, lamina lanceolate. Inflorescence is a dense and cylindrical panicle of spiklets $(3.5 \times 4 \mathrm{~mm}) \cdot 10-15 \mathrm{~cm}$ long 
bears spikelets in clusters of 1-3. Spikelets sessile, surrounded by two whorls of bristles; bristles ciliate, the inner longer and thicker than the outer, with one conspicuously longer (DeLisle, 1963). Spikelets with 2 florets, one sterile and one fertile, lanceolate, acute at apex. Upper and lower glumes $(4 \times 3 \mathrm{~mm}$, $2.8 \times 2 \mathrm{~mm}$ ) are similar in shape, hyaline, ovate, glabrous, with equal length of spikelets. Flower pedicllate, bracteates (lemma, 4 x $5 \mathrm{~mm}$ and palea, 4 x $4.5 \mathrm{~mm}$ of fertile floret are similar, ovate, hyaline and glabrous), zygomorphic, incomplete, bisexual, tepals 2 (free). Anthers 3, introse, versatile, polyandrous, dithecus, antitepalous, dehiscence longitudinal. Stigma 2, plumose, terminally excerted, ovary superior, monocarpellary, unilocular with basal placentation. Caryopsis oblong, glabarous and dorsally compressed, 2-5.5 x 1-1.5 mm (Fig. 1).
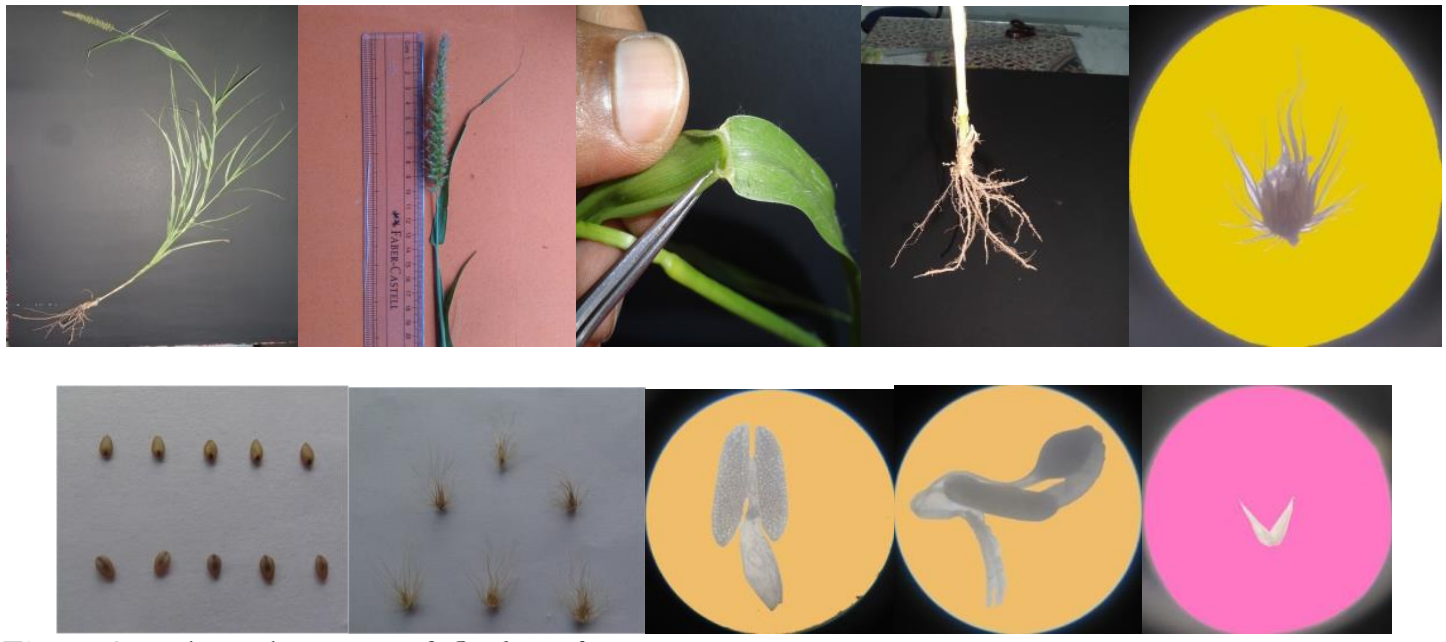

Figure 1. Various plant parts of Cenchrus ciliaris

\section{Cenchrus setigerus Vahl}

\section{Common name - Birdwood Grass}

Structurally almost similar except few new features and measurement adventitious roots $9-16 \mathrm{~cm}$ long. Culms 40-100 cm long with nodes and internodes (flattened, hairy with 1-2 grooves and $1-14.5 \mathrm{~cm} \times$ $5-10 \mathrm{~mm})$. Leaf ligulate $(11-55.5 \mathrm{~cm} \times 3-6.5 \mathrm{~mm})$. Panical $3.5-9.5 \mathrm{~cm}$ long. Rachis bears spikelets in clusters of 1-3, involucral bristles connate at base. Bristles numerous, rigid and spiny (Fig. 2).
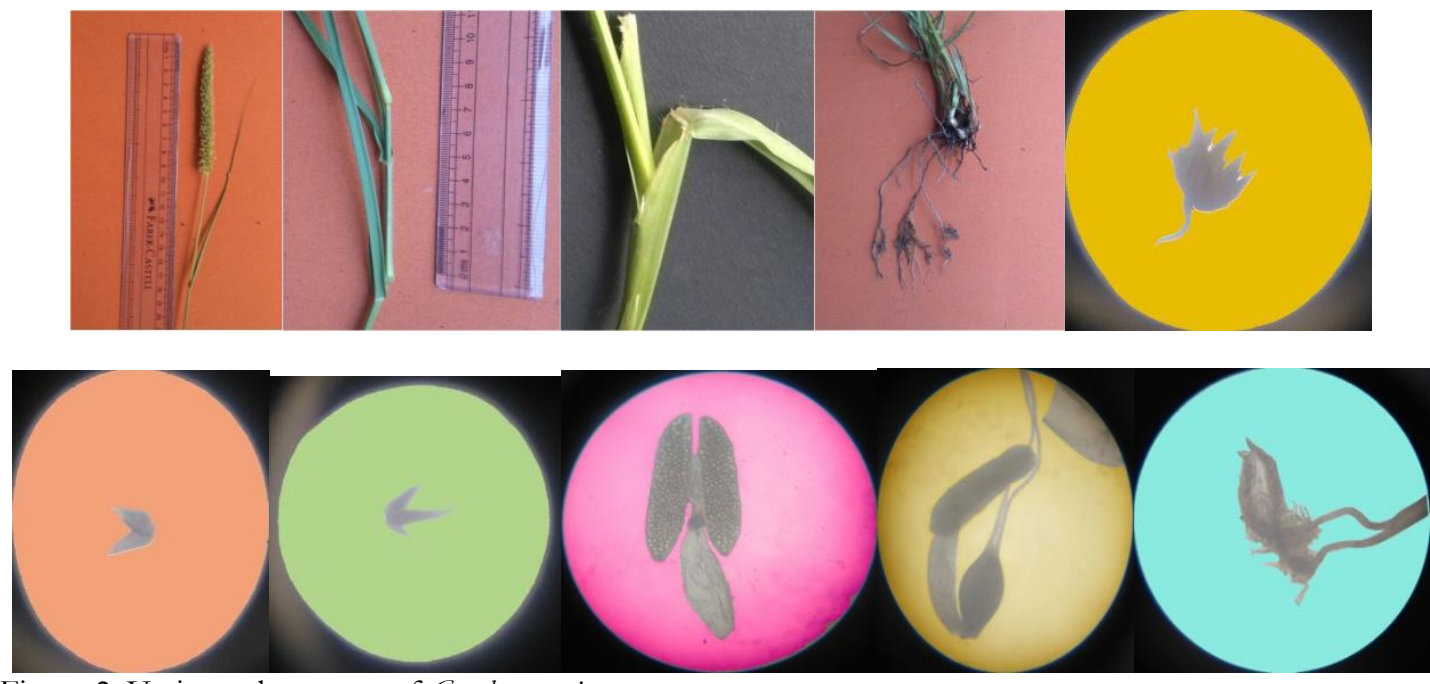

Figure 2. Various plant parts of Cenchrus setigerus

\section{Cenchrus biflorus Roxb.}

\section{Common name - Indian Sandbur}

Shows similar characters but it is an annual, tufted, glabarous grass species. Culms rooting at lower nodes. Upper internodes are longer than lower ones. Leaf blades $(12-36.5 \mathrm{~cm}$ long x 7-12 mm). Panical 9-14 cm x 7-15 mm.) bears deciduous spikelets subtended by a rigid involucral whorl of bristles (bur) connate at base. Outer bristles are short, spiny and numerous as compare to inner (Fig. 3). Cenchrus biflorus is well adapted to hot and dry tropical areas and might be a paleotropical invasive weed (Quattrocchi, 2008). 

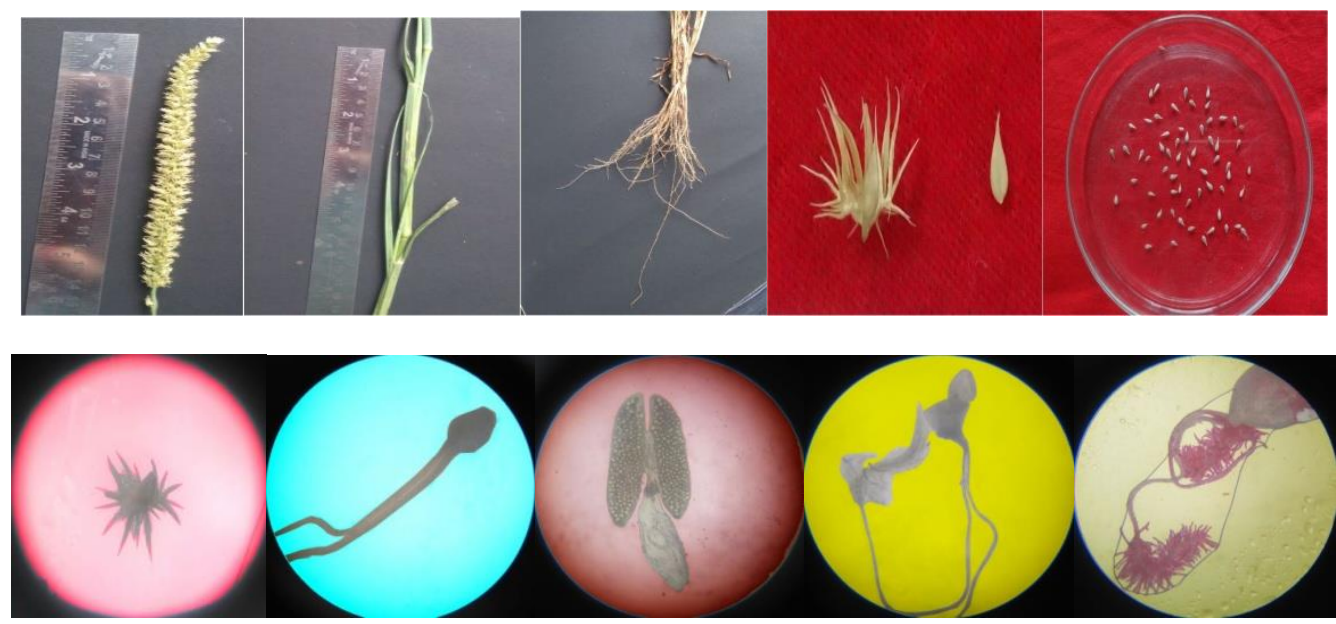

Figure 3. Various plant parts of Cenchrus biflorus

\section{Conclusion}

Morphological studies of the genus Cenchrus were carried out from Thar Desert. Observations on the species were recorded in the field as well as in the laboratory in their natural habitat and in living form. The results on plant morphological characteristics for the three species of Cenchrus fit well with the published literature on Cenchrus ciliaris (Goel et al., 2011; Saini et al., 2007; Chen and Kuoh, 2004), Cenchrus setigerus (Goel et al., 2011; Saini et al., 2007) and Cenchrus biflorus (Goel et al., 2011; Saini et al., 2007) except few differences of measurements. It may be because of climatic and habitat conditions or some other factor may cause such discrepancies. It has been observed that the biomass production and water uptake efficiency of this grass is better than other arid zone grasses that make it more potent and fit to harsh conditions of Thar Desert. Authors have analyzed so many medicinally important phytocompounds from this forage crop of high economic value (Arora et al., 2017; Arora and Kumar, 2017; Arora and Kumar, 2018). This grass is relatively resistant to drought and overgrazing, produces high forage productions as compare to cost of establishment. Still there is huge scope to enrich the information of other aspects related to this grass and a systematic study involving various aspects is required to exploit it fully.

\section{Acknowledgment}

Authors express sincere thanks to Prof. P.K. Kasera for providing academic support and the CAS Department of Botany J.N.V. University, Jodhpur (Rajasthan) for providing research facilities, infrastructure and technical support.

\section{References}

1. Chen Hui-Chih and Kuoh Chang-Sheng. Cenchrus ciliaris L., A newly naturalized grass in Taiwan. Taiwsania, 49.2 (2004) pp. 232-236.

2. Goel S, Singh HD and Raina SN. Cenchrus. In: Kole C. (ed) Wild Crop Relatives: Genomic and
Breeding Resources. Springer, Berlin, Heidelberg (2011).

3. M'Seddi K, Visser M, Neffati M, Reheul D and Chaieb M. Seed and spike traits from remnant populations of Cenchrus ciliaris L. in South Tunisia: high distinctiveness, no ecotypes. Journal of Arid Environment, 50 (2002) pp. 309-324.

4. Quattrocchi U. CRC world dictionary of grasses. Taylor \& Francis Group, Boca Raton, London, NewYork (2008).

5. Saini ML, Jain P and Joshi UN. Morphological characteristics and nutritive value of some grass species in an arid ecosystem. Grass and forage science, 62.10 (2007) pp. 104-108.

6. Stieber MT and Wipff JK. Cenchrus L. In Barkworth ME et al. (eds) Flora of North America north of Mexico, Vol 25, Oxford University Press, New York, Oxford (2003) pp. 529-535

7. Mandy Tu. The Nature Conservancy's Wildland Invasive Species Team, Deptt. of Vegetable Crops \& Weed Sciences, University of California, Davis, CA. https://www.invasive.org/gist/esadocs/documnts/ cenccil.pdf

8. USDA (2009). A National Genetic Resources Program. Germplasm resources information network- (GRIN). National Germplasm Resources Laboratory, Beltsville, Maryland, USA. http://www.invasive.org/gist/alert/alrtcenc.html

9. Visser M, Mseddi K, Chaieb $M$ and Neffati $M$. Assessing yield and yield stability of remnant populations of Cenchrus ciliaris L. in arid Tunisia: developing a blueprint for initiating native seed production. Grass and Forage Science, 63 (2008) pp. 301-313.

10. Arora S and Kumar G. GC-MS analysis of bioactive compounds from the stem of Cenchrus ciliaris from Thar Desert, Rajasthan (India). Advances in Plant Sciences, 29.2 (2016) pp. 271-274.

11. Sunita Arora and Ganesh Kumar. Screening and evaluation of bioactive components of Cenchrus 
ciliaris L. by GC-MS analysis. International Research Journal of Pharmacy, 8.6 (2017) pp. 69-76.

12. Arora S, Kumar G and Meena S. Gas chromatography-mass spectroscopy analysis of root of an economically important plant, Cenchrus ciliaris L. from Thar Desert, Rajasthan (India). Asian Journal of Pharmaceutical and Clinical Research, 10.9 (2017) pp. 64-69.

13. Arora S and Kumar G. GC-MS analysis of bioactive compounds from the whole plant hexane extract of Cenchrus setigerus Vahl. Pharma science Monitor, 8.4 (2017) pp. 137-146.
14. Arora S and Kumar G. Gas Chromatography-Mass Spectrometry (GC-MS) determination of bioactive constituents from the methanolic and ethyl acetate extract of Cenchrus setigerus Vahl (Poaceae). The Pharma Innovation Journal, 6.11 (2017) pp. 635-640.

15. Arora S and Kumar G. Phytochemical screening of root, stem and leaves of Cenchrus biflorus Roxb. Journal of Pharmacognosy and Phytochemistry, 7.1 (2018) pp. $1445-1450$.

\section{Cite this article as:}

Kumar G and Arora S. Comparative Morphological Screening of Some Species of Cenchrus L. (Poaceae) from Thar Desert of Rajasthan, India. Annals of Plant Sciences 7.4 (2018) pp. 2175-2178.

do $\mathrm{http://dx.doi.org/10.21746/aps.2018.7.4.2}$

Source of support: J.N.V. University, Jodhpur (Rajasthan)

Conflict of interest: Nil 